\title{
Cardiovascular risks and elevation of serum DHT vary by route of testosterone administration: a systematic review and meta-analysis
}

\author{
Stephen E Borst ${ }^{1,4^{*}}$, Jonathan J Shuster ${ }^{6}$, Baiming Zou ${ }^{5}$, Fan Ye ${ }^{2,4}$, Huanguang Jia ${ }^{2}$, Anita Wokhlu $\mathrm{u}^{3,7}$
} and Joshua F Yarrow ${ }^{2,4}$

\begin{abstract}
Background: Potential cardiovascular (CV) risks of testosterone replacement therapy (TRT) are currently a topic of intense interest. However, no studies have addressed CV risk as a function of the route of administration of TRT.

Methods: Two meta-analyses were conducted, one of CV adverse events (AEs) in 35 randomized controlled trials (RCTs) of TRT lasting 12 weeks or more, and one of 32 studies reporting the effect of TRT on serum testosterone and dihydrotestosterone (DHT).

Results: CV risks of TRT: Of 2,313 studies identified, 35 were eligible and included 3,703 mostly older men who experienced $218 \mathrm{CV}$-related AEs. No significant risk for CV AEs was present when all TRT administration routes were grouped (relative risk $(\mathrm{RR})=1.28,95 \%$ confidence interval $(\mathrm{Cl}): 0.76$ to $2.13, P=0.34)$. When analyzed separately, oral TRT produced significant $C V$ risk ( $R R=2.20,95 \% \mathrm{Cl}: 1.45$ to $3.55, P=0.015$ ), while neither intramuscular $(\mathrm{RR}=0.66,95 \%$ Cl: 0.28 to $1.56, P=0.32$ ) nor transdermal (gel or patch) TRT ( $R R=1.27,95 \% \mathrm{Cl}: 0.62$ to $2.62, P=0.48$ ) significantly altered CV risk. Serum testosterone/DHT following TRT: Of 419 studies identified, 32 were eligible which included 1,152 men receiving TRT. No significant difference in the elevation of serum testosterone was present between intramuscular or transdermal TRT. However, transdermal TRT elevated serum DHT (5.46-fold, $95 \% \mathrm{Cl}: 4.51$ to 6.60) to a greater magnitude than intramuscular TRT (2.20-fold, 95\% Cl: 1.74 to 2.77 ).

Conclusions: Oral TRT produces significant CV risk. While no significant effects on CV risk were observed with either injected or transdermal TRT, the point estimates suggest that further research is needed to establish whether administration by these routes is protective or detrimental, respectively. Differences in the degree to which serum DHT is elevated may underlie the varying CV risk by TRT administration route, as elevated serum dihydrotestosterone has been shown to be associated with CV risk in observational studies.
\end{abstract}

Keywords: Testosterone, DHT, Cardiovascular disease trials, Random effects, Meta-analysis

\section{Background}

Testosterone replacement therapy (TRT) is being utilized at a rapidly increasing rate, with 1.6 billion dollars in sales in the US in 2011 [1]. Proven benefits for older men with low testosterone $(\mathrm{T})$ levels include increases in muscle strength, exercise capacity, bone mineral density (BMD), libido and insulin sensitivity [2,3]. Meta-analysis through

\footnotetext{
* Correspondence: Stephen.borst@va.gov

${ }^{1}$ Geriatric Research, Education and Clinical Center, Malcom Randall VA Medical Center, 1601 SW Archer RD, Gainesville, FL 32605-1197, USA ${ }^{4}$ Department of Applied Physiology \& Kinesiology, University of Florida, Gainesville, USA

Full list of author information is available at the end of the article
}

2010 [4-6] confirmed three adverse events resulting from TRT: 1) polycythemia, 2) an increased number of prostate-related events, and 3) a small reduction in high density lipoprotein (HDL) cholesterol. Prostate events consist of the combined incidence of elevated prostatespecific antigen (PSA), prostate biopsy necessitated by results of digital rectal exam, increased urinary symptoms and prostate cancer [4]. A meta-analysis by Calof et al. shows no evidence that TRT increases prostate cancer (odds ratio $=1.09$ with no trend toward significance), when considered as an independent outcome [4]. However, the cardiovascular $(\mathrm{CV})$ risk of TRT is controversial $[5,6]$. 
Several recent reports have raised the concern that TRT may produce $\mathrm{CV}$ risks. In their randomized controlled trial (RCT) of transdermal T gel administration, Basaria et al. reported a very high incidence of CV adverse events (AEs) in treated subjects (21\%) compared to placebo (5\%) resulting in cessation of the trial [7]. More recently, Vigen et al., in a retrospective study of 8,709 hypogonadal men with a history of recent coronary angiography, reported a higher risk of the combined endpoints of myocardial infarction (MI), stroke and all-cause mortality in those who received any form of TRT (25.7\%) compared to those who did not (19.9\%) [8]. Another observational study by Finkle et al. evaluated 55,000 patients and reported a more than two-fold greater risk of $\mathrm{MI}$ in men who had received a TRT prescription [9]. Similarly, a meta-analysis by $\mathrm{Xu}$ et al. of CV AEs in $27 \mathrm{RCTs}$ administering TRT (reported through 2012) found that TRT produced a significantly greater number of $\mathrm{CV}$ AEs in TRT-treated participants compared to placebo (odds ratio (OR) 1.54, 95\% CI 1.09 to 2.18) and also made the disturbing observation that these AEs were under-reported in industry-sponsored studies [10]. However, the statistical methods employed in the latter study were not appropriate for low event-rate meta-analysis [11]. In contrast, Corona et al. [12] published a meta-analysis of 75 studies of TRT using less stringent inclusion criteria and found no evidence of $\mathrm{CV}$ risk $(\mathrm{OR}=1.07$ for all $\mathrm{CV}$ AEs; $\mathrm{OR}=1.01$ for serious $\mathrm{CV}$ AEs). In response to these reports, in 2014, the US Food and Drug Administration [13], the US Veteran's Administration [14] and the Endocrine Society [15] have all issued advisories regarding CV AEs resulting from TRT.

In contrast with the above reports, some of which indicate that TRT may be associated with $[8,9]$ or may cause $[7,10]$ increased $\mathrm{CV}$ events, there is an extensive literature supporting the $\mathrm{CV}$ benefits of adequate levels of endogenous $\mathrm{T}$ and TRT. In older men, low $\mathrm{T}$ is associated with increased $\mathrm{CV}$ risk and increased all-cause mortality [16]. Several studies have shown that TRT is beneficial in populations of older men with $\mathrm{CV}$ disease. English et al. have shown that TRT improves exercise capacity in men with angina [17]. In addition, Toma and colleagues [18] have published a meta-analysis demonstrating improved New York Heart Association (NYHA) class, six minute walk time and peak oxygen consumption after TRT in men with systolic heart failure [18]. Furthermore, in a large retrospective cohort study of more than 6,000 intramuscular TRT users and matched controls, Baillargeon et al. reported no increase in CV events in myocardial infarction hospitalization rates in all TRT-treated subjects and reduced rates in those who were in the quartile with the highest risk factors for CV disease [19].

One potential explanation for these apparently conflicting observations is that the $\mathrm{CV}$ risk/benefit ratio may vary by the route of TRT administration. Testosterone can be administered by intramuscular injection of longacting $\mathrm{T}$ esters, transdermally by patch or gel and orally as testosterone undecanoate (TU). Different routes of administration are typically associated with different doses, different time courses of serum androgen elevation and different relative levels of dihydrotestosterone (DHT) relative to testosterone. Transdermally and orally administered $\mathrm{T}$ are exposed to a high degree of 5-alpha reductase activity present in the skin [20] and liver [21], respectively, possibly increasing serum DHT relative to testosterone, which may affect $\mathrm{CV}$ risk. Shores et al. recently reported that serum DHT is independently and positively associated with incident CV disease [22], incident stroke [23], and all-cause mortality [22]. In contract, in a cohort of 1,032 elderly men followed for a median of nine to ten years, neither circulating $\mathrm{T}$ nor free $\mathrm{T}$ were associated with the latter adverse outcomes.

The main purpose of this meta-analysis was to assess whether the incidence of $\mathrm{CV}$ events is affected by the mode of TRT administration. Our secondary purpose was to determine if there is a differential elevation of $\mathrm{T}$ versus DHT based on route of TRT administration. We postulate that the latter may be a potential mechanism for differential CV effects.

\section{Methods}

\section{Data sources and searches}

This meta-analysis follows the Preferred Reporting Items for Systematic Reviews and Meta-Analyses (PRISMA) checklist [see Additional file 1]. Two expert authors searched for and selected the studies, agreed upon the eligibility of each study and extracted information from the selected trials (SB, FY). We systematically searched PubMed until 31 May 2014 using two search strategies: 1) ("testosterone" or "androgen") and (random") and "trial" and 2) "testosterone" and "clinical trials". Studies of men, published in English were selected and the search was supplemented by a search of the World Health Organization trial registry and by a manual search of bibliographies of identified studies (SB and FY). To identify studies reporting the elevation of serum $\mathrm{T}$ and DHT following TRT, we performed a supplemental search using the terms: "testosterone" and "DHT" and ("injection" or "gel" or "patch" or "oral") that included all TRT clinical trials in men because few studies report DHT concentrations before and after TRT.

\section{Study selection}

\section{CV risks following TRT}

We included only placebo-controlled RCTs of TRT that reported CV related events for both the TRT and placebo arms. We excluded trials where testosterone secretion was experimentally suppressed prior to initiation of TRT 
because these studies do not have a true placebo group. In order to assess the long-term, rather than the acute, effects of TRT, we included only trials lasting 12 weeks or more. Initially, we intended to exclude RCTs that only reported AEs necessitating study withdrawal, however this turned out to be a fine distinction and so we included any RCT that reported CV events by treatment arm. In order to ensure that we did not include more than one study using the same data set, we checked for duplication based on authorship, study description, number of participants, and participant characteristics. Where duplication occurred, we used the report containing the most comprehensive description of AEs.

\section{Elevation of serum $T$ and DHT following TRT}

Few placebo-controlled RCTs report both serum $\mathrm{T}$ and DHT before and after treatment. For this reason, we broadened our search to include all TRT trials that reported both serum $\mathrm{T}$ and DHT, before and after treatment, regardless of study duration or whether the study was blinded. We have recently shown that commercially available methods for measuring DHT by immunoassay are invalid [24]. For this reason, we also excluded one study where DHT was measured by immunoassay [25]. We also removed any duplication of studies as described above.

\section{Outcome}

The primary outcome was composite CV events because we anticipated too few events to allow for analysis by individual event type. CV events were defined as anything reported as such in the original study. In cases where authors sent us a table of all AEs, we (SEB and AW - Cardiologist) defined CV AEs using International Statistical Classification of Disease (ICD) 10 codes [see Additional file 2]. CV events in individual studies are listed in Additional file 3. The secondary outcome was elevation of serum $\mathrm{T}$ and DHT following TRT administration by different routes (intramuscular, transdermal (patch or gel) or oral).

\section{Data extraction and quality assessment}

Data for CV AEs and elevation of serum $\mathrm{T}$ and DHT were extracted by trial arm by SB and FY. Event classification was checked by a cardiologist (AW). Reviewers (SB and FY) used an established tool to evaluate the quality of each trial [26] [see Additional file 4 and Additional file 5]. If the trial did not report CV AEs or did not do so by treatment arm, we contacted the authors twice by email to ask for additional information [see Additional file 6]. Studies were excluded if CV event incidence could not be determined with the above method.

\section{Statistical methods \\ $C V$ events analysis}

It is important to note that this collection of studies involves low event-rate randomized binomial trials. Since the trials involve diverse interventions, random effects are mandatory, whether or not a Cochran Q test fails to reject homogeneity (Borenstein et al. [27], section titled 'Model should not be based on the test for heterogeneity'). In addition, commonly used methods based on inverses of variance estimators such as the DerSimonian-Laird method are not valid in this arena. The Cochrane Handbook [28], section 16.9, states 'Methods that should be avoided with rare events are the inverse-variance methods (including the DerSimonian and Laird (DL) [29] random-effects method). Xu et al. [10] used a fixed effects meta-regression with inverse variance weights in their previous meta-analysis, and as such, this was not an acceptable approach when event rates are low. Furthermore, compared with a random effects model, a fixed effects model makes the strong assumption that the true effect size for all studies is identical and the inference from a fixed effects model is conditional and limited to the studies included in the meta-analysis [30]. The methodology we employ is the sample size weighted random effects method of Shuster et al. [11], specifically designed for low event-rate meta-analysis, and which has been vetted on nearly 40,000 low event scenarios. Given the issues with low event-rate meta-analysis, ignored in $\mathrm{Xu}$ et al., it is critically important to reanalyze those data in this paper. Note that we employ RR, the estimate of the ratio of failure rates, rather than the OR, the ratio of the odds of failure. $\mathrm{RR}$ and $\mathrm{OR}$ are very similar when event rates are low, but RRs are far easier to understand.

\section{Analysis of serum $T$ and DHT levels}

For laboratory levels, we used a minor modification of the patient weighted random effects method of Shuster [31], using the more conservative t-distribution (degrees of freedom $=$ number of studies -1 ) instead of the normal approximation. In our experience this is a better large sample approximation. Means are sample-weighted. The individual study fold changes were analyzed (not the ratio of the summary post-test estimate to the summary pre-test estimate).

\section{Results}

Study selection and characteristics for analysis of CV risks The initial search yielded 2,313 publications, of which 197 were subjected to further scrutiny. As shown in Figure 1, we subsequently identified 35 unique publications of placebo-controlled RCTs of TRT in men that reported $\mathrm{CV}$ events and met our search criteria. The study design and patient characteristics across these trials are summarized in Table 1 . The 35 studies of TRT include 


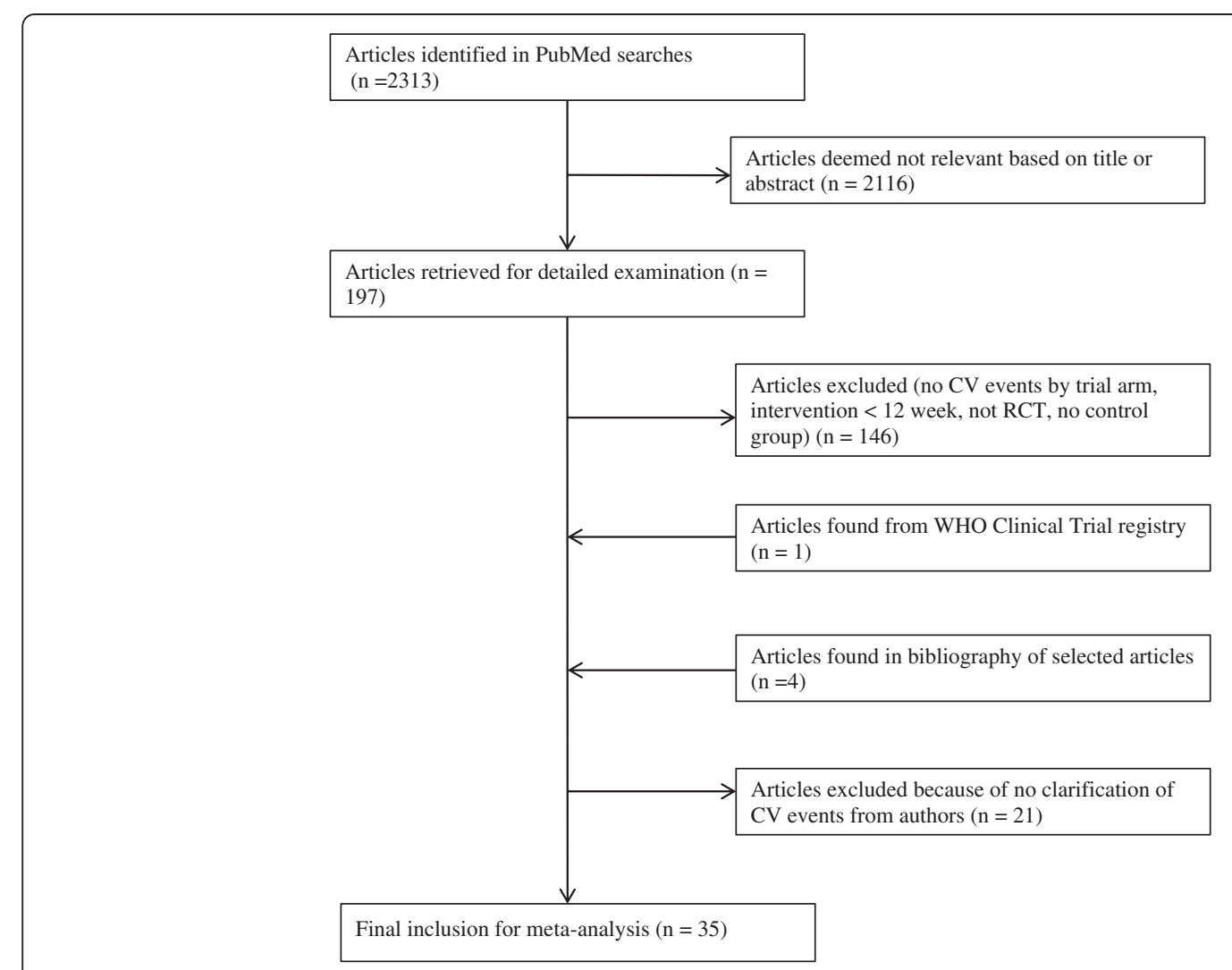

Figure 1 Selection process for placebo-controlled randomized clinical trials (RCTs) of testosterone replacement therapy (TRT) on CV events.

3,703 men, typically older than 45 years, with low $\mathrm{T}$ and/ or chronic diseases. Of the 35 trials, 16 studies administered TRT intramuscularly, 15 transdermally (10 gel and 5 patch), and 4 orally. The mean duration of treatment was 11.9 months.

\section{Risk of CV events based on route of TRT}

Of the 3,703 subjects, 2,114 receiving TRT had $131 \mathrm{CV}$ related events $(6.2 \%)$, while 1,589 receiving placebo had 87 (5.5\%) CV-related events. Two trials were stopped early, one because of AEs in the TRT arm [7] and one because a beneficial effect of TRT was 'not foreseeable' [32]. Additional file 3 shows a comprehensive list of the type and severity of the $218 \mathrm{CV}$ events (if specified) in the TRT and placebo groups.

As shown in Figure 2, among patients receiving any form of TRT, the estimated RR for CV events was 1.28 (95\% CI 0.76 to $2.13, P=0.34$ ) which was not statistically significant. However, CV event rates varied by mode of TRT administration. Specifically, oral TRT resulted in a significant increase in CV events (estimated $\mathrm{RR}=2.20$, $95 \%$ CI 1.45 to $3.35, P=0.015)$. In contrast, neither intramuscular TRT (estimated RR $=0.66,95 \%$ CI 0.28 to 1.56 , $P=0.32$ ) nor transdermal (patch or gel) TRT (estimated $\mathrm{RR}=1.27,95 \%$ CI 0.62 to $2.62, P=0.48$ ) significantly affected CV events.
Re-analysis of $\mathrm{Xu}$ et al. [10]: Using the same patientweighted method [31], the estimated relative risk for $\mathrm{CV}$ AEs is 1.59 (95\% CI $=0.90$ to 2.57 ), $P=0.059$, not quite statistically significant, whereas Xu et al. [10] using inverse variance weighted methods (against the advice of the Cochrane Handbook), reported a point estimate of 1.54 (95\% CI $=1.09$ to 2.18 ).

\section{Route of TRT and elevation of serum T and DHT Levels}

As shown in Figure 3, the initial search yielded 419 publications, of which 56 were subjected to further scrutiny. We subsequently identified 31 unique publications that met our criteria and which included 1,176 men who received TRT (see Table 2). Elevation of serum DHT, but not $\mathrm{T}$, was significantly affected by TRT administration mode (see Table 3). Specifically, intramuscular TRT elevated serum $\mathrm{T}$ and DHT to a roughly similar degree. In contrast, transdermal TRT elevated DHT to a significantly greater degree (5.46-fold, 95\% CI 4.51 to 6.60 ) than intramuscular TRT (2.20-fold, (95\% CI 1.74 to 2.77). Only four oral TRT studies were identified that reported both $\mathrm{T}$ and $\mathrm{DHT}$, and the data were insufficient for statistical analysis. However, oral TRT appeared to produce a post-treatment serum $\mathrm{T}$ that was similar with other administration routes and very high post-treatment serum DHT values. 
Table 1 Characteristics of placebo-controlled randomized clinical trials of testosterone replacement therapy (TRT) reporting CV events

\begin{tabular}{|c|c|c|c|c|c|c|c|c|}
\hline Author/Year & Mode & Dose & Study duration & Age & $\begin{array}{l}\text { Subjects in } \\
\text { TRT group }\end{array}$ & $\begin{array}{l}\text { Subjects in } \\
\text { placebo group }\end{array}$ & Serum $T$ at entry & Health status \\
\hline Amory 2004 [32] & i.m. & 100 mg TE/week & 36 months & $71 \pm 4(S D)$ & 24 & 24 & $302 \pm 48(S D) n g / d L$ & hypogonadal \\
\hline Aversa 2010 [33] & i.m. & 1,000 mg TU/12 week & 24 months & $58 \pm 10$ (SD) & 40 & 10 & $259 \pm 48(\mathrm{SD}) \mathrm{ng} / \mathrm{dL}$ & hypogonadal \\
\hline Borst 2014 [34] & i.m. & 125 mg TE/week & 12 months & $69.2 \pm 8.0(\mathrm{SD})$ & 31 & 29 & $264 \pm 92(\mathrm{SD}) \mathrm{ng} / \mathrm{dL}$ & hypogonadal \\
\hline Caminiti 2009 [35] & i.m. & 1,000 mg TU/8 week & 4.5 months & 66 to 76 & 35 & 35 & $230 \pm 180$ (SD) ng/dL & hypogonadal, heart failure \\
\hline Ferrando 2002 [36] & i.m. & 100 mg TE/week & 6 months & $67 \pm 3(S D)$ & 7 & 5 & $<480 \mathrm{ng} / \mathrm{dL}$ & eugonadal \\
\hline Hackett 2014 [37] & i.m. & $1000 \mathrm{mg}$ TU/6 to 12 weeks & 7.5 months & 18 to 80 & 97 & 102 & $301 \pm 11$ (SD) ng/dL & hypogonadal, type 2 diabetes \\
\hline Hall 1996 [38] & i.m. & 250 mg TE/4 weeks & 9 months & $60.8 \pm 9.7(S D)$ & 17 & 18 & $458 \pm 187(\mathrm{SD}) \mathrm{ng} / \mathrm{dL}$ & eugonadal, rheumatoid arthritis \\
\hline Ho 2011 [39] & i.m. & $1,000 \mathrm{mg}$ TU/10 to 14 weeks & 24 months & $\geq 40$ & 60 & 60 & $<345 \mathrm{ng} / \mathrm{dL}$ & low normal T \\
\hline Hoyos 2012 [40] & i.m. & 1,000 mg TU/6 weeks & 4.5 months & $49 \pm 12(S D)$ & 33 & 34 & $388 \pm 152(\mathrm{SD}) \mathrm{ng} / \mathrm{dL}$ & eugonadal, obese, sleep apnea \\
\hline Kalichenko 2010 [41] & i.m. & $1,000 \mathrm{mg}$ TU/6 to 12 weeks & 7.5 months & 49 to 53 & 113 & 71 & $<345 \mathrm{ng} / \mathrm{dL}$ & low normal T, metabolic syndrome \\
\hline Kenny 2004 [42] & i.m. & 200 mg TE/3 weeks & 3 months & $81 \pm 5(S D)$ & 6 & 5 & $410 \pm 112(\mathrm{SD}) \mathrm{ng} / \mathrm{dL}$ & mild cognitive impairment \\
\hline Sih 1997 [43] & i.m. & 200 mg TC/2 weeks & 12 months & $65 \pm 7$ (SD) & 17 & 15 & $233 \pm 20(\mathrm{SD}) \mathrm{ng} / \mathrm{dL}$ & hypogonadal \\
\hline Svartberg 2004 [44] & i.m. & 250 mg TE/4 weeks & 6 months & $64 \pm 6.5$ (SD) & 15 & 14 & $590 \pm 164$ (SD) ng/dL & eugonadal, COPD \\
\hline Svartberg 2008 [45] & i.m. & $1,000 \mathrm{mg}$ TU/6 to 12 weeks & 12 months & $69 \pm 5(S D)$ & 19 & 19 & $239 \pm 54(\mathrm{SD}) \mathrm{ng} / \mathrm{dL}$ & hypogonadal \\
\hline Sheffield-Moore 2011 [46] & i.m. & 100 mg TE/week & 5 months & $73 \pm 8(S D)$ & 8 & 8 & $<500 \mathrm{ng} / \mathrm{dL}$ & eugonadal \\
\hline Tan 2013 [47] & i.m. & 1,000 mg TU/8 weeks & 12 months & $53.8 \pm 8.3(\mathrm{SD})$ & 56 & 58 & $<345 \mathrm{ng} / \mathrm{dL}$ & low normal T \\
\hline *Basaria 2010 [7] & gel & 100 to $150 \mathrm{mg}$ T/day & 6 months* & $74 \pm 5$ (SD) & 106 & 103 & $250 \pm 57(\mathrm{SD}) \mathrm{ng} / \mathrm{dL}$ & hypogonadal, mobility limited \\
\hline Brockenbrough 2006 [48] & gel & 100 mg T/day & 6 months & $58.9 \pm 14.9(\mathrm{SD})$ & 19 & 21 & $218 \pm 64$ (SD) ng/dL & hypogonadal, renal disease \\
\hline Glintborg 2013 [49] & gel & 50 to 100 mg T/day & 6 months & 62 to 72 & 20 & 18 & $<210 \mathrm{ng} / \mathrm{dL}$ & hypogonadal, obese \\
\hline Hildreth 2013 [50] & gel & 25 to $50 \mathrm{mg}$ T/day & 12 months & $66.6 \pm 5.8(S D)$ & 96 & 47 & $294 \pm 38$ (SD) ng/dL & hypogonadal \\
\hline Jones 2011 [51] & gel & $60 \mathrm{mg}$ T/day & 12 months & 37 to 77 & 108 & 112 & $265 \pm 75$ (SD) ng/dL & hypogonadal, metabolic syndrome \\
\hline Kaufman 2011 [52] & gel & 20 to 80 mg T/day & 6 months & $53.6 \pm 9.5(\mathrm{SD})$ & 234 & 40 & mean $=294 \mathrm{ng} / \mathrm{dL}$ & hypogonadal \\
\hline Kenny 2010 [53] & gel & $50 \mathrm{mg}$ T/day & 12 to 24 months & $79.9 \pm 7.3(\mathrm{SD})$ & 69 & 62 & $380 \pm(S D) n g / d L$ & eugonadal, osteoporosis \\
\hline Marin 1993 [54] & gel & 125 mg T/day & 9 months & $56.7 \pm 2.2(\mathrm{SD})$ & 11 & 10 & $434 \pm 23(\mathrm{SD}) \mathrm{ng} / \mathrm{dL}$ & eugonadal, obese \\
\hline Spitzer 2012 [55] & gel & 100 to 300 mg T/day & 3.5 months & $55.1 \pm 8.3(\mathrm{SD})$ & 70 & 70 & $248 \pm 62(\mathrm{SD}) \mathrm{ng} / \mathrm{dL}$ & hypogonadal, erectile dysfunction \\
\hline Srinivas-Shankar 2010 [56] & gel & $50 \mathrm{mg}$ T/day & 6 months & $73.7 \pm 5.7(S D)$ & 138 & 136 & $313 \pm 89(\mathrm{SD}) \mathrm{ng} / \mathrm{dL}$ & low normal $\mathrm{T}$, frail \\
\hline English 2000 [17] & patch & $5 \mathrm{mg}$ T/day & 3 months & $69 \pm 2(S D)$ & 25 & 25 & $390 \pm 22(\mathrm{SD}) \mathrm{ng} / \mathrm{dL}$ & eugonadal, stable angina \\
\hline Malkin 2006 [57] & patch & $5 \mathrm{mg}$ T/day & 12 months & $63.1 \pm 10.7(S D)$ & 37 & 39 & $400 \pm 152(S D) \mathrm{ng} / \mathrm{dL}$ & eugonadal, heart failure \\
\hline Merza 2005 [58] & patch & $5 \mathrm{mg}$ T/day & 6 months & $63 \pm 9$ (SD) & 20 & 19 & $242 \pm 95(\mathrm{SD}) \mathrm{ng} / \mathrm{dL}$ & hypogonadal \\
\hline Nair 2006 [59] & patch & $5 \mathrm{mg}$ T/day & 24 months & 61 to 72 & 27 & 31 & bioavailable $\mathrm{T}<103 \mathrm{ng} / \mathrm{dL}$ & hypogonadal \\
\hline Snyder 2001 [60] & patch & 6 mg T/day & 36 months & $71.3 \pm 5.8(\mathrm{SD})$ & 54 & 54 & $<475$ ng/dL & eugonadal \\
\hline Chapman 2009 [61] & oral & 160 mg TU/day & 12 months & $78 \pm 4(S D)$ & 11 & 12 & $541 \pm 35$ (SD) ng/dL & eugonadal, undernourished \\
\hline
\end{tabular}


Table 1 Characteristics of placebo-controlled randomized clinical trials of testosterone replacement therapy (TRT) reporting CV events (Continued)

\begin{tabular}{lllllll}
\hline Copenhagen study 1986 [62 $]^{\text {a }}$ oral & 600 mg micronized T/day & 8 to 62 months & 24 to 79 & 134 & 87 & not measured
\end{tabular}
600 mg micronized T/day

$\begin{array}{ll}\text { to } 62 \text { months } & 24 \text { to } 79 \\ \text { months } & 67.1 \pm 5.0\end{array}$

oral 80 to $240 \mathrm{mg}$ TU/day

12 months

$58.6 \pm 5.7(\mathrm{SD}) \quad 237$

117

$316 \pm 54$ (SD)

coholic cirrhosis

Legros 2009 [64] (c) obstructive pulmonary diseas

79 free $T<7.5 \mathrm{ng} / \mathrm{dL}$

hypogonadal

aStudy was stopped early. COPD. chronic obstructive pulmonary disease; i.m., intramuscular; SD, standard deviation; T, testosterone; TC, testosterone cypionate; TE, testosterone enanthate; TU,

testosterone undecanoate. 


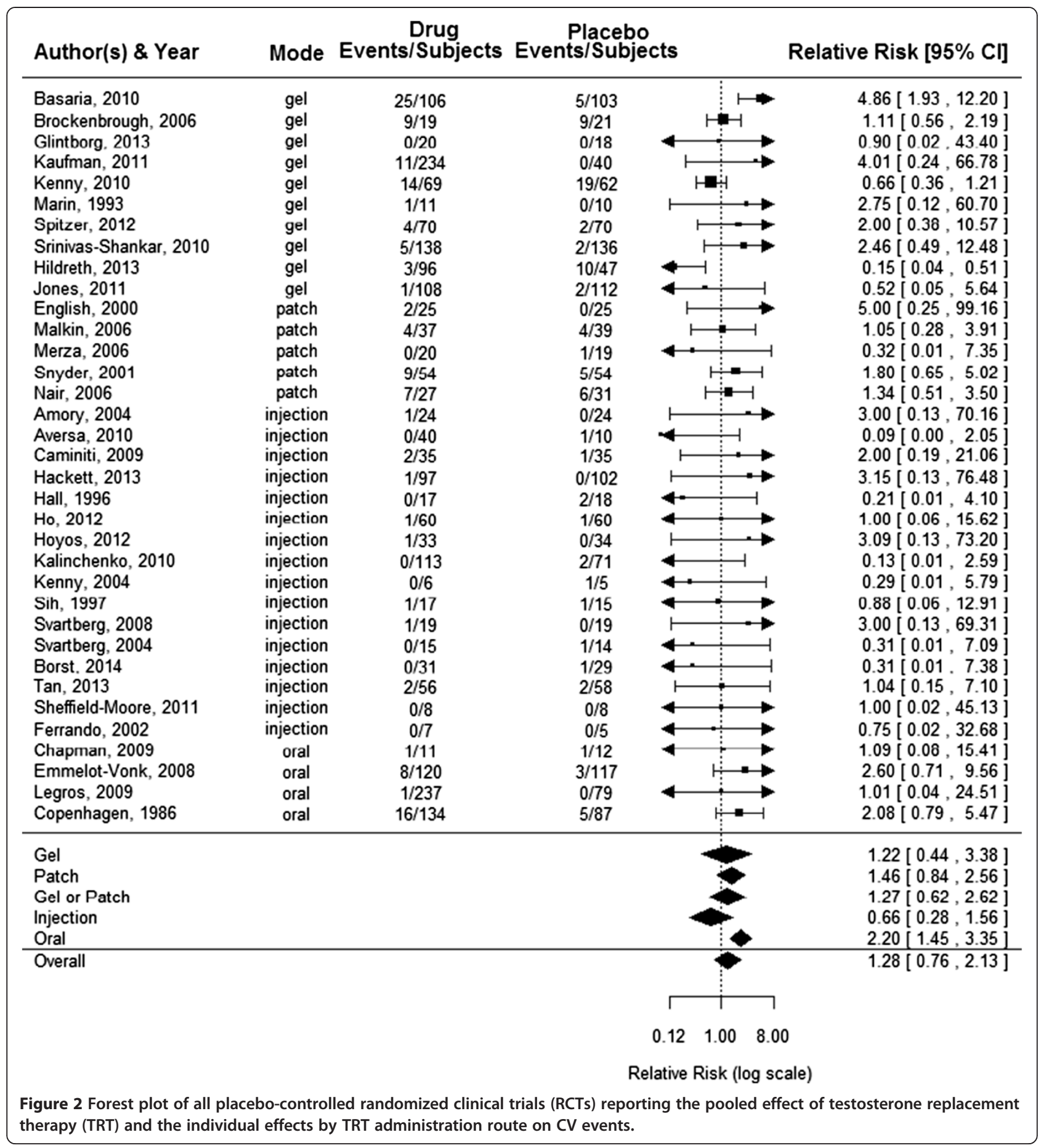

\section{Discussion}

This meta-analysis of 35 eligible studies and more than 3,700 patients receiving TRT is the largest consolidation of RCT data thus far. Our main finding is that no significant increase in CV event risk was noted among studies of various TRT administration routes when analyzed together. Further, when the risk of CV events was analyzed based on the mode of administration, only oral
TRT was associated with elevated CV risk when compared with placebo. The increase in $\mathrm{CV}$ risk resulting from transdermal TRT and the decrease in CV risk seen with intramuscular TRT did not achieve statistical significance. A second important finding in this meta-analysis is that the oral and transdermal administration methods of TRT are associated with greater DHT elevations than intramuscular administration. Because there is emerging 


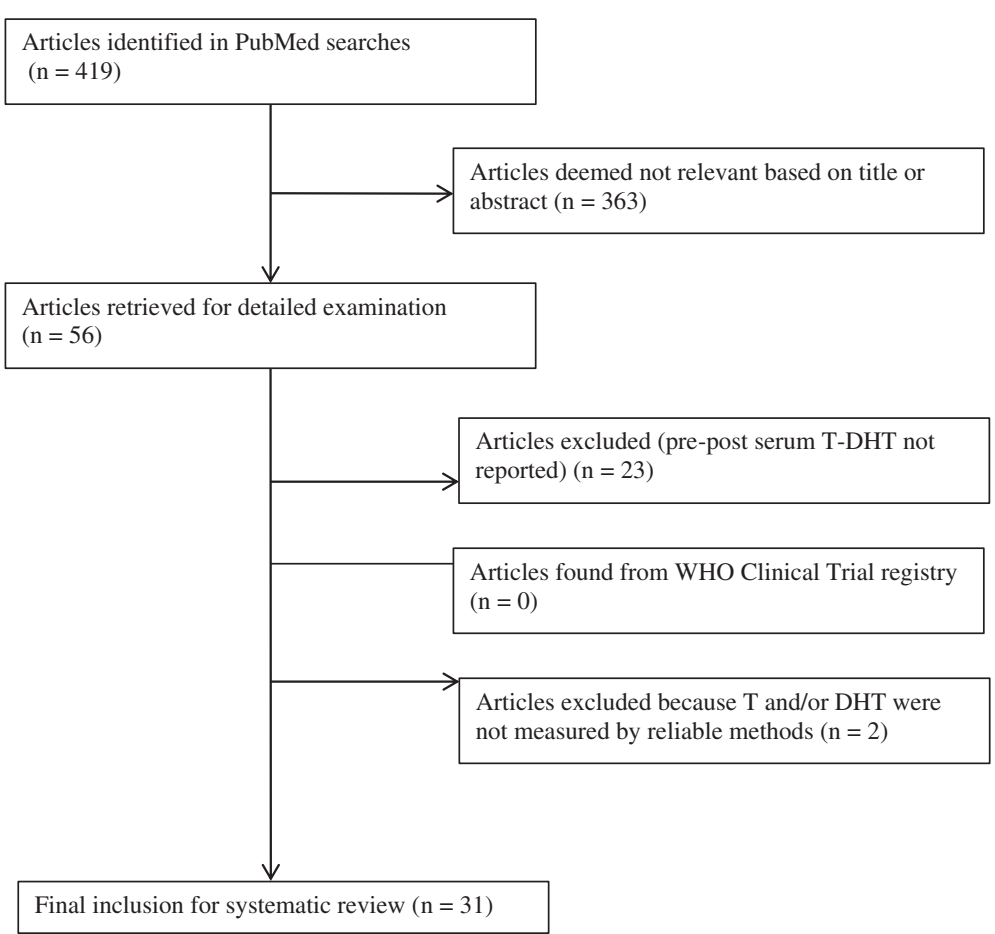

Figure 3 Selection process for clinical trials reporting both serum testosterone (T) and dihydrotestosterone (DHT) concentrations before and after testosterone replacement therapy (TRT).

data demonstrating an association between elevated DHT (rather than serum T) and adverse CV events, these two findings may have important implications for our current understanding of the mechanisms of CV risk in TRT recipients.

\section{Mode of administration and CV risk}

Our finding that there are varying CV risks based on the type of TRT formulation helps reconcile seemingly disparate observations across various studies regarding testosterone's CV effects. While three prior meta-analyses suggested no significant increase in CV risk across TRT RCTs [4-6], a more recent meta-analysis by Xu et al. [10] indicated higher $\mathrm{CV}$ risk with TRT. The present meta-analysis is the most extensive thus far. Although we included all reported $\mathrm{CV}$ AEs in this meta-analysis, we have included newer studies exclusive to this review which may reflect less publication bias, more rigorous patient screening practices and more attention to the reporting of hard CV endpoints rather than nonspecific $\mathrm{CV}$ events that may have driven $\mathrm{AE}$ rates in previous studies.

The increased CV risk of the oral formulation subgroup is a novel finding in our analysis. While no significant effects on $C V$ risk were observed with either injected or transdermal TRT, the point estimates suggest that further research is needed to establish whether administration by these routes is protective or detrimental, respectively. To the best of our knowledge, differing $\mathrm{CV}$ risk specific to varying testosterone formulations has not been previously reported.

\section{DHT elevation and increased CV risk}

The greater elevation of DHT that occurs with oral or transdermal TRT may be due to the high expression of 5 - $\alpha$ reductase in skin [20] and liver [21] in comparison to lower 5- $\alpha$ reductase in skeletal muscle [89]. The finding of differential DHT elevation may be critical to our understanding of adverse CV risk, because elevated serum DHT (not elevated T) has recently been found to be associated with CV risk in several observational studies. Shores et al. published two studies of 1,032 older men which reported significant associations between the serum DHT concentration and both the 10-year rate of incident ischemic stroke [23] and the 9-year rate of incident CV disease and all-cause mortality [16] (see Figure 4). Interestingly, similar relationships did not exist for serum total or free $\mathrm{T}$, suggesting that $\mathrm{CV}$ risk resulting from TRT may result from the $5 \alpha$-reduction of T to DHT. In both studies by Shores et al., the lowest risk was associated with a serum DHT concentration of approximately $60 \mathrm{ng} / \mathrm{dL}$, while greater risk was associated with both higher and lower DHT concentrations.

In Figure 4, the left panel represents data from our meta-analysis showing the elevation of serum DHT with intramuscular, transdermal and oral TRT. In the center and right panels, we have superimposed that data on top 
Table 2 Characteristics of testosterone replacement therapy (TRT) trials reporting both serum testosterone (T) and dihydrotestosterone (DHT) concentrations before and after treatment

\begin{tabular}{|c|c|c|c|c|c|c|c|c|}
\hline Author/Year & Study type & Mode & Dose & Duration & Age & Subjects in TRT group & Serum $T$ at entry & Health status \\
\hline Amory 2004 [32] & RCT & i.m. & 100 mg TE/week & 36 months & $71 \pm 4$ (SD) & 24 & $302 \pm 48$ (SD) ng/dL & hypogonadal \\
\hline Arver 1997 [65] & open-label & i.m. & 266 mg TE/26 days & 3 weeks & $58 \pm 10(S D)$ & 27 & $121 \pm 100$ (SD) ng/dL & hypogonadal \\
\hline Bhasin 2012 [66] & RCT & i.m. & 125 mg TE/week & 5 months & $40 \pm 7$ (SD) & 12 & 519 ng/dL (mean) & eugonadal \\
\hline Borst 2014 [34] & RCT & i.m. & 125 mg TE/week & 12 months & $69.2 \pm 8.0(S D)$ & 31 & $264 \pm 92(\mathrm{SD}) \mathrm{ng} / \mathrm{dL}$ & hypogonadal \\
\hline Lakshman 2010 [67] & RCT & i.m. & 125 mg TE/week & 5 months & $65.6 \pm 4.3(\mathrm{SD})$ & 11 & $581 \pm 168(S D)$ ng/dL & eugonadal \\
\hline Raynaud 2008 [68] & open-label & i.m. & 250 mg TE/3 weeks & 12 months & $41.8 \pm 12.4(S D)$ & 32 & 43 ng/dL (mean) & hypogonadal \\
\hline Shubert 2003 [69] & open-label & i.m. & 250 mg TE/3 weeks & 12 months & $31.9 \pm 2.5(\mathrm{SD})$ & 14 & 63.6 ng/dL \pm 14 (SD) & hypogonadal \\
\hline Wang 2010 [70] & open-label & i.m. & $750 \mathrm{mg}$ TU/4 to 10 weeks & 21 months & $>18$ & 117 & 320 ng/dL \pm 111 (SD) & low normal T \\
\hline Brockenbrough 2006 [48] & RCT & gel & 10 mg T/day & 6 months & $58.9 \pm 14.9(\mathrm{SD})$ & 19 & $218 \pm 64(\mathrm{SD}) \mathrm{ng} / \mathrm{dL}$ & hypogonadal, renal disease \\
\hline Cherrier 2003 [71] & RCT & gel & 50-100 mg T/day & 6 months & 34 to 70 & 12 & $320 \pm 90(S D) n g / d L$ & low normal T \\
\hline Chiang 2007 [72] & RCT & gel & $50 \mathrm{mg}$ T/day & 3 months & 20 to 75 & 17 & $213 \pm 158$ (SD) ng/dL & hypogonadal \\
\hline Dean 2004 [73] & open-label & gel & $50 \mathrm{mg}$ T/day & 9 months & 58.5 (mean) & 257 & 247 ng/dL (mean) & hypogonadal \\
\hline Di Luigi 2012 [74] & open-label & gel & $50 \mathrm{mg}$ T/day & 1.25 month & $31.3 \pm 7.5(\mathrm{SD})$ & 10 & 72 ng/dL (mean) & hypogonadal \\
\hline Juang 2014 [75] & RCT & gel & 100 mg T/day & 3.5 months & 24 to 51 & 14 & $302 \pm 37(S D) \mathrm{ng} / \mathrm{dL}$ & hypogonadal, osteoporosis \\
\hline Kenny 2010 [53] & RCT & gel & $50 \mathrm{mg}$ T/day & 12 months & $79.9 \pm 7.3(\mathrm{SD})$ & 69 & $380 \pm 179$ (SD) ng/dL & eugonadal, osteoporosis \\
\hline Marin 1993 [54] & RCT & gel & 125 mg T/day & 9 months & $56.7 \pm 2.2(\mathrm{SD})$ & 10 & $455 \pm 23(\mathrm{SD}) \mathrm{ng} / \mathrm{dL}$ & eugonadal, obese \\
\hline Mazer 2005 [76] & RCT & gel & 59 mg/day & 2 weeks & $52.4 \pm 12.2(\mathrm{SD})$ & 28 & $226 \pm 110$ (SD) ng/dL & hypogonadal \\
\hline Page 2011 [77] & RCT & gel & 75 mg T/day & 6 months & $>50$ & 27 & 204 ng/dL (mean) & hypogonadal, BPH \\
\hline Swerdloff 2000 [78] & open-label & gel & 100 mg T/day & 3 months & 51.3 (mean) & 76 & 280 ng/dL (mean) & hypogonadal \\
\hline Wang 2000 [79] & no placebo group & gel & 100 mg T/day & 2 weeks & 26 to 59 & 10 & $179 \pm 41$ (SD) ng/dL & hypogonadal \\
\hline Wang 2011 [80] & open-label & gel & $60 \mathrm{mg}$ T/day & 4 months & $51.5 \pm 12.7(\mathrm{SD})$ & 135 & $215 \pm 84(\mathrm{SD}) \mathrm{ng} / \mathrm{dL}$ & hypogonadal \\
\hline Ahmed 1988 [81] & no placebo group & patch & 15 mg T/day & 6 to 8 weeks & 34 to 54 & 5 & $45 \pm 12(\mathrm{SD}) \mathrm{ng} / \mathrm{dL}$ & hypogonadal \\
\hline Bals-Pratch 1988 [82] & not stated & patch & 10 to 15 mg T/day & 14 months & 31 to 37 & 7 & 189 ng/dL (mean) & hypogonadal \\
\hline Behre 1999 [83] & open-label & patch & 2.4 to $3.6 \mathrm{mg} \mathrm{T/day}$ & 7 years & $35.9 \pm 9.8$ (SD) & 11 & $147 \pm 37(\mathrm{SD}) \mathrm{ng} / \mathrm{dL}$ & hypogonadal \\
\hline Cunningham 1989 [84] & placebo-controlled & patch & 15 mg T/day & 8 weeks & 33 to 66 & 12 & $43 \pm 11$ (SD) ng/dL & hypogonadal \\
\hline Mazer 2005 [76] & open-label & patch & $5 \mathrm{mg}$ T/day & 2 weeks & 28 to 71 & 28 & $215 \pm 110$ (SD) ng/dL & hypogonadal \\
\hline Meikle 1992 [85] & not stated & patch & 12.6 mg T/day & single dose & 24 to 66 & 6 & $161 \pm 27(\mathrm{SD}) \mathrm{ng} / \mathrm{dL}$ & hypogonadal \\
\hline Raynaud 2008 [68] & open-label & patch & $2.5 \mathrm{mg}$ T/day & 12 months & $40.7 \pm 10.5$ (SD) & 131 & 43 ng/dL (mean) & hypogonadal \\
\hline Franchimont 1978 [86] & & oral & 120 to 240 mg TU/day & 9 weeks & 16 to 51 & 10 & 120 ng/dL (mean) & hypogonadal \\
\hline
\end{tabular}


Table 2 Characteristics of testosterone replacement therapy (TRT) trials reporting both serum testosterone (T) and dihydrotestosterone (DHT) concentrations before and after treatment (Continued)

\begin{tabular}{|c|c|c|c|c|c|c|c|c|}
\hline Roth 2011 [87] & open-label & oral & 400 mg TU/day & 1 day & 18 to52 & 11 & $405 \pm 14$ (SD) ng/dL & eugonadal \\
\hline Schubert 2003 [69] & open-label & oral & 160 mg TU/day & 12 months & $34.5 \pm 3.9(\mathrm{SD})$ & 13 & 63.6 ng/dL \pm 14 (SD) & hypogonadal \\
\hline Van Coevorden 1986 [88] & $\mathrm{RCT}$ & oral & 240 mg TU/day & 12 weeks & $40 \pm 11$ (SD) & 19 & $161 \pm 86(\mathrm{SD}) \mathrm{ng} / \mathrm{dL}$ & hypogonadal, renal insufficiency \\
\hline
\end{tabular}

$\overline{\mathrm{BPH}}$, benign prostate hyperplasia; $\mathrm{RCT}$, randomized clinical trial; $\mathrm{SD}$, standard deviation; $\mathrm{TE}$, testosterone enanthate; $\mathrm{TU}$, testosterone undecanoate. 
Table 3 Change in serum testosterone (T) and dihydrotestosterone (DHT) when assessed by testosterone replacement therapy (TRT) administration route

\begin{tabular}{|c|c|c|c|c|c|c|c|}
\hline \multirow[b]{2}{*}{$\begin{array}{l}\text { Route of } \\
\text { administration }\end{array}$} & \multirow[b]{2}{*}{ Number of studies } & \multicolumn{3}{|l|}{ Testosterone } & \multicolumn{3}{|l|}{ DHT } \\
\hline & & $\begin{array}{l}\text { Pre-treatment T } \\
\text { (nmol/L) }(95 \% \mathrm{Cl})\end{array}$ & $\begin{array}{l}\text { Post-treatment T } \\
\text { (nmol/L) }(95 \% \mathrm{Cl})\end{array}$ & $\begin{array}{l}\text { Pre-Post treatment fold } \\
\text { increase in } \mathrm{T}(95 \% \mathrm{Cl})\end{array}$ & $\begin{array}{l}\text { Pre-treatment DHT } \\
\text { (nmol/L) }(95 \% \mathrm{Cl})\end{array}$ & $\begin{array}{l}\text { Post-treatment DHT } \\
\text { (nmol/L) }(95 \% \mathrm{Cl})\end{array}$ & $\begin{array}{l}\text { Pre-Post treatment fold } \\
\text { increase in } \mathrm{DHT}(95 \% \mathrm{Cl})\end{array}$ \\
\hline Intramuscular & 8 & 9.27 (5.68 to 12.85$)$ & 23.11 (15.38 to 34.72 ) & 2.91 (2.19 to 3.86 ) & 1.02 (0.69 to 1.34$)$ & 1.62 (1.2 to 2.19$)$ & 2.20 (1.74 to 2.77$)$ \\
\hline $\begin{array}{l}\text { Transdermal } \\
\text { (patch and gel) }\end{array}$ & 20 & 7.28 (6.09 to 8.42 ) & 16.69 (12.62 to 21.98$)$ & 2.53 (1.83 to 3.50$)$ & 0.99 (0.78 to 1.20$)$ & 3.43 (2.37 to 4.98$)$ & 5.46 (4.51 to 6.60$)$ \\
\hline Gel & 13 & 8.90 (7.67 to 10.13$)$ & 18.3 (15.18 to 23.12$)$ & 1.98 (1.70 to 2.30$)$ & 1.19 (0.93 to 1.46$)$ & 3.81 (2.57 to 5.63$)$ & 5.12 (4.07 to 6.45$)$ \\
\hline Patch & 7 & 4.20 (2.78 to 5.23$)$ & 9.73 (4.01 to 23.62) & 4.43 (2.99 to 6.54$)$ & 0.62 (0.36 to 0.88 ) & 2.16 (0.68 to 6.87 ) & 6.61 (3.08 to 14.16$)$ \\
\hline \multirow[t]{2}{*}{ Oral ${ }^{\mathrm{a}}$} & 4 & 6.66 & 21.88 & 2.80 & 0.90 & 3.92 & 4.46 \\
\hline & & $(14.05,2.9,5.6,4.1)$ & $(59.2,5.70,7.6,14.96)$ & $(4.20,2.20,1.4,3.6)$ & $(1.1,1.8,0.30,0.41)$ & $(9.89,3.30,1.13,1.35)$ & $9.0,1.8,3.8,3.3$ \\
\hline
\end{tabular}

${ }^{\mathrm{a} E f f e c t s}$ of oral TRT on T and DHT concentrations were not statistically analyzed because only four studies were identified that met our a priori inclusionary criteria, which resulted in sufficient data. For oral studies, the mean and individual values for each of the four studies are listed. Transdermal (patch or gel) TRT produces a greater elevation of serum DHT than intramuscular TRT. Means are adjusted for sample size. 


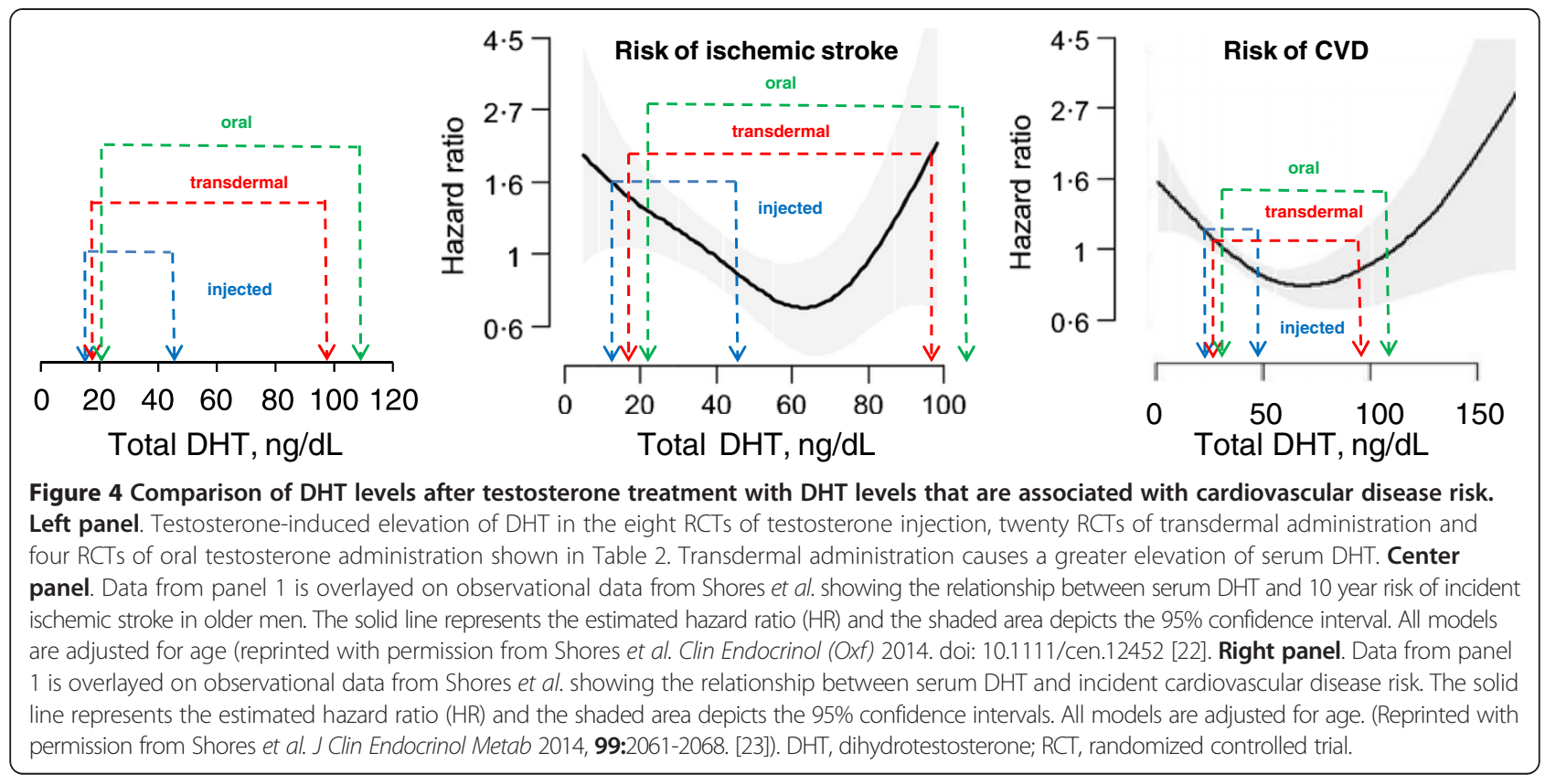

of the previously published data from the two papers by Shores et al. Taken together, these data appear to indicate that intramuscular TRT elevates the serum DHT concentration into a range that is associated with reduced $\mathrm{CV}$ disease (CVD) and stroke risks. In contrast, transdermal and oral TRT appear to elevate serum DHT into a range that is associated with unchanged CVD risk and increased ischemic stroke risk.

\section{Limitations}

Reporting of AEs may be open to interpretation and so may vary somewhat among trials. Using the most serious $\mathrm{CV}$ events (stroke, myocardial infarction, and CV-related death) might be more unambiguous. Because of very long follow-up periods, such events are common enough to assess in observational studies [16,22,23]. However, due to shorter study duration, serious $\mathrm{CV}$ events are not common enough to study in clinical trials of TRT. As a result, our analyses are based on all $\mathrm{CV}$ events, serious or not.

The data on oral TRT must be interpreted with caution, since only four studies met the inclusion criteria. Of those, two had very low rates of $\mathrm{CV}$ events in both the treated and placebo groups $[61,64]$ and one study had very high post-treatment serum $\mathrm{T}$ concentrations [32], possibly due to the presence of liver disease in the study subjects. The latter study was not included in the analysis of TRT-induced elevations of T/DHT because DHT was not measured. However, among the four studies analyzed for T/DHT, there was considerable variation in serum concentrations. Variation may result from the fact that serum $\mathrm{T}$ concentrations are not sustained following oral TRT and the time of blood acquisition is therefore critical.

Two studies included in the analysis of $\mathrm{CV}$ risk were stopped early. One study of oral TRT was stopped because of lack of evidence for efficacy unrelated to CV [32] and one study of gel TRT was stopped early for excess CV events in the group receiving testosterone [7]. The first study, whose stopping was uninfluenced by $\mathrm{CV}$ has no bias associated with early stopping. The second, may actually be associated with a slight bias estimate away from the null, actually strengthening the null conclusion. There is no way to adjust for this without serial patient level data and the exact stopping rules used.

Interpretation of the data on TRT-induced elevations of $\mathrm{T}$ and DHT may be limited by the fact that DHT was assayed by several methods in the included studies. The latter include mass spectroscopy (MS) based methods and various radioimmunoassays (RIAs). MS-based assays provide highly accurate measurements of DHT. RIAs are specific for DHT [90] but the values are somewhat higher than those obtained with MS-based assays [91]. The enzyme-linked immunosorbant assay (EIA) for DHT is not valid as we have recently shown [24] and studies using this method were excluded. The current analysis is based on clinical trials that have a high rate of compliance. An additional limitation in extending our findings to a clinical setting is that compliance may be lower. Schoenfeld et al. have shown that TRT gel adherence is only $37.4 \%$ at six months [92]. Similarly, Donatucci et al. [93] reported that at three months, adherence to transdermal TRT was $52 \%$ and adherence to injected TRT was $32 \%$. 


\section{Potential cardiovascular benefits of testosterone}

Although this paper encompasses a discussion of adverse $\mathrm{CV}$ risk of TRT, assessment of the $\mathrm{CV}$ risk-to-benefit should be considered. Numerous studies have demonstrated positive CV effects of TRT. English et al. [17] have shown that, in men with stable angina, treatment with low-dose $\mathrm{T}$ ( $5 \mathrm{mg}$ /day by patch) for 12 weeks caused a significant $17 \%$ increase in time to $1-\mathrm{mm}$ ST segment depression during treadmill exercise testing. Stout et al. [94] have shown that TRT administration to men with chronic heart failure increases maximal oxygen consumption $\left(\mathrm{VO}_{2 \max }\right)$ and improves physical performance. Toma et al. [18] published a meta-analysis of the four studies showing that TRT improved exercise capacity in heart failure patients. Empen et al. [95] reported that $\mathrm{T}$ deficiency is associated with impaired arterial flow-mediated dilation (FMD), a marker of vascular endothelial function. Cardiovascular improvement with TRT is thought to result from increased coronary blood flow, peripheral vasodilation, positive remodeling of skeletal muscle and reduced insulin resistance, without marked effects on left ventricular ejection fraction [18].

\section{Conclusions}

The potential CV risks of TRT are currently being debated. This updated meta-analysis indicates oral TRT produces increased CV risk, while TRT administered by all routes may cause an increase in CV adverse events, but the effect is not statistically significant. On the latter point, a definitive answer awaits further clinical trials. More studies are also needed to assess whether increased $\mathrm{CV}$ risk occurs with the transdermal formulations and decreased CV risk with the intramuscular formulation. This early indicator that intramuscular $\mathrm{T}$ may be safer than transdermal TRT may be surprising, considering that intramuscular TRT doses are typically several-fold higher than transdermal doses. However, our data indicate that transdermal TRT produces a significantly greater elevation of serum DHT than intramuscular $\mathrm{T}$, possibly due to the expression of 5-alpha reductase in the skin. Interestingly, serum DHT concentrations following intramuscular TRT correspond to DHT levels that are associated with reduced $\mathrm{CV}$ risk in other large observational studies, suggesting that: 1) CV risks of TRT administration may result from excessive elevation of serum DHT; and 2) intramuscular TRT may produce less CV risk than transdermal or oral TRT. Given our unique findings, future RCTs, metaanalyses and retrospective database studies evaluating the health risks associated with TRT should carefully control for the change in serum DHT and evaluate the TRT administration route as potential confounding factors in their data analysis.

\section{Additional files}

Additional file 1: PRISMA 2009 Checklist.
Additional file 2: ICD 10 codes for cardiovascular disease.

Additional file 3: Listing of CV events in RCTs selected for analysis of CV events.

Additional file 4: Quality assessment for RCTs reporting the effect of TRT on CV events.

Additional file 5: Quality assessment for trials reporting elevation of serum T and DHT following TRT.

Additional file 6: Inclusion of RCTs for analysis of CV events following attempts to obtain additional information from authors.

\section{Competing interests}

The authors declare that they have no competing interests.

\section{Authors' contributions}

SEB participated in study conception and design, performed searches, contacted authors for additional information and drafted the manuscript. JJS and BZ performed statistical analysis and participated in revisions of the manuscript. FY performed searches, contacted authors for additional information, and participated in revisions of the manuscript. HJ participated in revision of the manuscript. AW assessed descriptions of cardiovascular events and participated in revisions of the manuscript. JFY participated in study conception and design and in revisions of the manuscript. All authors read and approved the final manuscript.

\section{Acknowledgements}

This work was partially supported by a VA Merit Award to SEB and by NIH grant 1UL1TR000064 from the National Center for Advancing Translational Sciences.

\section{Author details}

${ }^{1}$ Geriatric Research, Education and Clinical Center, Malcom Randall VA Medical Center, 1601 SW Archer RD, Gainesville, FL 32605-1197, USA. ${ }^{2}$ Research Service, Malcom Randall VA Medical Center, Gainesville, FL, USA. ${ }^{3}$ Medicine Service, Malcom Randall VA Medical Center, Gainesville, FL, USA. ${ }^{4}$ Department of Applied Physiology \& Kinesiology, University of Florida, Gainesville, USA. ${ }^{5}$ Department of Biostatistics, University of Florida, Gainesville, USA. ${ }^{6}$ Department of Health Outcomes and Policy, University of Florida, Gainesville, USA. 7 Department of Medicine-Cardiovascular Division, University of Florida, Gainesville, USA.

Received: 9 September 2014 Accepted: 14 October 2014

Published online: 27 November 2014

\section{References}

1. Spitzer M, Huang G, Basaria S, Travison TG, Bhasin S: Risks and benefits of testosterone therapy in older men. Nat Rev Endocrinol 2013, 9:414-424.

2. Tracz MJ, Sideras K, Bolona ER, Haddad RM, Kennedy CC, Uraga MV, Caples SM, Erwin PJ, Montori VM: Testosterone use in men and its effects on bone health: A systematic review and meta-analysis of randomized placebo-controlled trials. J Clin Endocrinol Metabol 2006, 91:2011-2016.

3. Traish AM: Outcomes of testosterone therapy in men with testosterone deficiency (TD): Part II. Steroids 2014, 88:117-126.

4. Calof OM, Singh AB, Lee ML, Kenny AM, Urban RJ, Tenover JL, Bhasin S: Adverse events associated with testosterone replacement in middle-aged and older men: a meta-analysis of randomized, placebo-controlled trials. J Gerontol A Biol Sci Med Sci 2005, 60:1451-1457.

5. Fernandez-Balsells MM, Murad MH, Lane M, Lampropulos JF, Albuquerque F, Mullan RJ, Agrwal N, Elamin MB, Gallegos-Orozco JF, Wang AT, Erwin PJ, Bhasin S, Montori VM: Clinical review 1: Adverse effects of testosterone therapy in adult men: a systematic review and meta-analysis. J Clin Endocrinol Metab 2010, 95:2560-2575.

6. Haddad RM, Kennedy CC, Caples SM, Tracz MJ, Bolona ER, Sideras K, Uraga MV Erwin PJ, Montori VM: Testosterone and cardiovascular risk in men: a systematic review and meta-analysis of randomized placebo-controlled trials. Mayo Clin Proc 2007, 82:29-39. 
7. Basaria $S$, Coviello AD, Travison TG, Storer TW, Farwell WR, Jette AM, Eder $R$, Tennstedt S, Ulloor J, Zhang A, Choong K, Lakshman KM, Mazer NA, Miciek R, Krasnoff J, Elmi A, Knapp PE, Brooks B, Appleman E, Aggarwal S, Bhasin G, Hede-Brierley L, Bhatia A, Collins L, LeBrasseur N, Fiore LD, Bhasin S: Adverse events associated with testosterone administration. N Engl J Med 2010, 363:109-122.

8. Vigen R, O'Donnell Cl, Baron AE, Grunwald GK, Maddox TM, Bradley SM, Barqawi A, Woning G, Wierman ME, Plomondon ME, Rumsfeld JS, Ho PM: Association of testosterone therapy with mortality, myocardial infarction, and stroke in men with low testosterone levels. JAMA 2013, 310:1829-1836.

9. Finkle WD, Greenland S, Ridgeway GK, Adams JL, Frasco MA, Cook MB, Fraumeni JF Jr, Hoover RN: Increased risk of non-fatal myocardial infarction following testosterone therapy prescription in men. PLoS One 2014, 9:e85805.

10. Xu L, Freeman G, Cowling BJ, Schooling CM: Testosterone therapy and cardiovascular events among men: a systematic review and metaanalysis of placebo-controlled randomized trials. BMC Med 2013, 11:108.

11. Shuster JJ, Guo JD, Skyler JS: Meta-analysis of safety for low event-rate binomial trials. Res Synth Meth 2012, 3. doi:10.1002/jrsm.1039.

12. Corona G, Maseroli E, Rastrelli G, Isidori AM, Sforza A, Mannucci E, Maggi M: Cardiovascular risk associated with testosterone-boosting medications: a systematic review and meta-analysis. Expert Opin Drug Saf 2014, 13:1327-1351

13. Testosterone Products: Drug Safety Communication - FDA Investigating Risk of Cardiovascular Events. 31 January 2014. [http://www.fda.gov/safety/ medwatch/safetyinformation/safetyalertsforhumanmedicalproducts/ ucm384225.htm]

14. Department of Veterans Affairs VHA Pharmacy Benefits Management Advisory Panel: Testosterone Products and Cardiovascular Safety. 7 February 2014. [http://www.pbm.va.gov/PBM/vacenterformedicationsafety/ nationalpbmbulletin/Testosterone_Products_and_Cardiovascular_Safety_ NATIONAL_PBM_BULLETIN_02.pdf]

15. Endocrine Society Statement on the Risk of Cardiovascular Events in Men Receiving Testosterone Therapy Available. In [https://www. endocrine.org/membership/email-newsletters/endocrine-insider/2014/ february-20-2014/society-statement-risk-of-cardiovascular-events-in-menreceiving-testosterone-therapy-available]

16. Shores MM, Smith NL, Forsberg CW, Anawalt BD, Matsumoto AM: Testosterone treatment and mortality in men with low testosterone levels. J Clin Endocrinol Metab 2012, 97:2050-2058.

17. English KM, Steeds RP, Jones TH, Diver MJ, Channer KS: Low-dose transdermal testosterone therapy improves angina threshold in men with chronic stable angina: a randomized, double-blind, placebo-controlled study. Circulation 2000, 102:1906-1911.

18. Toma M, McAlister FA, Coglianese EE, Vidi V, Vasaiwala S, Bakal JA, Armstrong PW, Ezekowitz JA: Testosterone supplementation in heart failure: a meta-analysis. Circ Heart Fail 2012, 5:315-321.

19. Baillargeon J, Urban RJ, Kuo YF, Ottenbacher KJ, Raji MA, Du F, Lin YL, Goodwin JS: Risk of myocardial infarction in older men receiving testosterone therapy. Ann Pharmacother 2014, 48:1138-1144.

20. Inui S, Itami S: Androgen actions on the human hair follicle: perspectives. Exp Dermatol 2013, 22:168-171.

21. Thigpen AE, Silver RI, Guileyardo JM, Casey ML, McConnell JD, Russell DW: Tissue distribution and ontogeny of steroid 5 alpha-reductase isozyme expression. J Clin Invest 1993, 92:903-910.

22. Shores MM, Biggs ML, Arnold AM, Smith NL, Longstreth WT Jr, Kizer JR, Hirsch CH, Cappola AR, Matsumoto AM: Testosterone, dihydrotestosterone and incident cardiovascular disease and mortality in the cardiovascular health study. J Clin Endocrinol Metab 2014, 99:2061-2068.

23. Shores MM, Arnold AM, Biggs ML, Longstreth WT Jr, Smith NL, Kizer JR, Cappola AR, Hirsch CH, Marck BT, Matsumoto AM: Testosterone and dihydrotestosterone and incident ischaemic stroke in men in the Cardiovascular Health Study. Clin Endocrinol (Oxf) 2014, 81:746-753.

24. Yarrow JF, Beck DT, Conover CF, Beggs LA, Goldberger BA, Borst SE: Invalidation of a commercially available human 5alphadihydrotestosterone immunoassay. Steroids 2013, 78:1220-1225.

25. Gooren $L$, Saad F, Haide A, Yassin A: Decline of plasma 5alphadihydrotestosterone (DHT) levels upon testosterone administration to elderly men with subnormal plasma testosterone and high DHT levels. Andrologia 2008, 40:298-302.

26. Verhagen AP, de Vet $H C$, de Bie RA, Kessels AG, Boers M, Bouter LM, Knipschild PG: The Delphi list: a criteria list for quality assessment of randomized clinical trials for conducting systematic reviews developed by Delphi consensus. J Clin Epidemiol 1998, 51:1235-1241.

27. Borenstein $M$, Hedges LV, Higgins J, Rothstein HR: A basic introduction to fixed-effect and random-effects models for meta-analysis. Res Synth Meth 2010, 1:97-111.

28. Higgins JP, Green S (Eds): Cochrane Handbook for Systematic Reviews for Interventions, Version 5.1.0. Chichester, UK: Wiley Publications; 2011.

29. DerSimonian R, Laird N: Meta-analysis in clinical trials. Control Clin Trials 1986, 7:177-188.

30. Hedges $L V$, Vevea JL: Fixed - and random-effects models in meta-analysis. Psychol Methods 1998, 3:486-504.

31. Shuster JJ: Empirical vs natural weighting in random effects meta-analysis. Stat Med 2010, 29:1259-1265.

32. Amory JK, Watts NB, Easley KA, Sutton PR, Anawalt BD, Matsumoto AM, Bremner WJ, Tenover JL: Exogenous testosterone or testosterone with finasteride increases bone mineral density in older men with low serum testosterone. J Clin Endocrinol Metab 2004, 89:503-510.

33. Aversa A, Bruzziches R, Francomano D, Rosano G, Isidori AM, Lenzi A, Spera G: Effects of testosterone undecanoate on cardiovascular risk factors and atherosclerosis in middle-aged men with late-onset hypogonadism and metabolic syndrome: results from a 24-month, randomized, double-blind, placebo-controlled study. J Sex Med 2010, 7:3495-3503.

34. Borst SE, Yarrow JF, Conover CF, Nseyo U, Meuleman JR, Lipinska JA, Braith RW, Beck DT, Martin JS, Morrow M, Roessner S, Beggs LA, McCoy SC, Cannady DF 2nd, Shuster JJ: Musculoskeletal and prostate effects of combined testosterone and finasteride administration in older hypogonadal men: a randomized, controlled trial. Am J Physiol Endocrinol Metab 2014, 306:E433-E442.

35. Caminiti G, Volterrani M, lellamo F, Marazzi G, Massaro R, Miceli M, Mammi C, Piepoli M, Fini M, Rosano GM: Effect of long-acting testosterone treatment on functional exercise capacity, skeletal muscle performance, insulin resistance, and baroreflex sensitivity in elderly patients with chronic heart failure a double-blind, placebo-controlled, randomized study. J Am Coll Cardiol 2009, 54:919-927.

36. Ferrando AA, Sheffield-Moore M, Yeckel CW, Gilkison C, Jiang J, Achacosa A, Lieberman SA, Tipton K, Wolfe RR, Urban RJ: Testosterone administration to older men improves muscle function: molecular and physiological mechanisms. Am J Physiol Endocrinol Metab 2002, 282:E601-E607.

37. Hackett G, Cole N, Bhartia M, Kennedy D, Raju J, Wilkinson P, Saghir A, Blast Study Group: The response to testosterone undecanoate in men with type 2 diabetes is dependent on achieving threshold serum levels (the BLAST study). Int J Clin Pract 2014, 68:203-215.

38. Hall GM, Larbre JP, Spector TD, Perry LA, Da Silva JA: A randomized trial of testosterone therapy in males with rheumatoid arthritis. Br J Rheumatol 1996, 35:568-573.

39. Ho CC, Tong SF, Low WY, Ng CJ, Khoo EM, Lee VK, Zainuddin ZM, Tan HM: A randomized, double-blind, placebo-controlled trial on the effect of long-acting testosterone treatment as assessed by the Aging Male Symptoms scale. BJU Int 2012, 110:260-265.

40. Hoyos CM, Yee BJ, Phillips CL, Machan EA, Grunstein RR, Liu PY: Body compositional and cardiometabolic effects of testosterone therapy in obese men with severe obstructive sleep apnoea: a randomised placebo-controlled trial. Eur J Endocrinol 2012, 167:531-541.

41. Kalinchenko SY, Tishova YA, Mskhalaya GJ, Gooren LJ, Giltay EJ, Saad F: Effects of testosterone supplementation on markers of the metabolic syndrome and inflammation in hypogonadal men with the metabolic syndrome: the double-blinded placebo-controlled Moscow study. Clin Endocrinol (Oxf) 2010, 73:602-612.

42. Kenny AM, Fabregas G, Song C, Biskup B, Bellantonio S: Effects of testosterone on behavior, depression, and cognitive function in older men with mild cognitive loss. J Gerontol A Biol Sci Med Sci 2004, 59:75-78.

43. Sih R, Morley JE, Kaiser FE, Perry HM 3rd, Patrick P, Ross C: Testosterone replacement in older hypogonadal men: a 12-month randomized controlled trial. J Clin Endocrinol Metab 1997, 82:1661-1667.

44. Svartberg J, Aasebo U, Hjalmarsen A, Sundsfjord J, Jorde R: Testosterone treatment improves body composition and sexual function in men with COPD, in a 6-month randomized controlled trial. Respir Med 2004, 98:906-913.

45. Svartberg J, Agledahl I, Figenschau Y, Sildnes T, Waterloo K, Jorde R: Testosterone treatment in elderly men with subnormal testosterone levels improves body composition and BMD in the hip. Int J Impot Res 2008, 20:378-387. 
46. Sheffield-Moore M, Dillon EL, Casperson SL, Gilkison CR, Paddon-Jones D, Durham WJ, Grady JJ, Urban RJ: A randomized pilot study of monthly cycled testosterone replacement or continuous testosterone replacement versus placebo in older men. J Clin Endocrinol Metab 2011, 96:E1831-E1837.

47. Tan WS, Low WY, Ng CJ, Tan WK, Tong SF, Ho C, Khoo EM, Lee G, Lee BC, Lee $V$, Tan HM: Efficacy and safety of long-acting intramuscular testosterone undecanoate in aging men: a randomised controlled study. BJU Int 2013, 111:1130-1140.

48. Brockenbrough AT, Dittrich MO, Page ST, Smith T, Stivelman JC, Bremner WJ: Transdermal androgen therapy to augment EPO in the treatment of anemia of chronic renal disease. Am J Kidney Dis 2006, 47:251-262.

49. Glintborg D, Christensen LL, Kvorning T, Larsen R, Brixen K, Hougaard DM, Richelsen B, Bruun JM, Andersen M: Strength training and testosterone treatment have opposing effects on migration inhibitor factor levels in ageing men. Mediators Inflamm 2013, 2013:539156.

50. Hildreth KL, Barry DW, Moreau KL, Vande Griend J, Meacham RB, Nakamura T, Wolfe P, Kohrt WM, Ruscin JM, Kittelson J, Cress ME, Ballard R, Schwartz $\mathrm{RS}$ : Effects of testosterone and progressive resistance exercise in healthy, highly functioning older men with low-normal testosterone levels. J Clin Endocrinol Metab 2013, 98:1891-1900.

51. Jones TH, Arver S, Behre HM, Buvat J, Meuleman E, Moncada I, Morales AM, Volterrani M, Yellowlees A, Howell JD, Channer KS, TIMES2 Investigators: Testosterone replacement in hypogonadal men with type 2 diabetes and/or metabolic syndrome (the TIMES2 study). Diabetes Care 2011, 34:828-837.

52. Kaufman JM, Miller MG, Garwin JL, Fitzpatrick S, McWhirter C, Brennan JJ: Efficacy and safety study of $1.62 \%$ testosterone gel for the treatment of hypogonadal men. J Sex Med 2011, 8:2079-2089.

53. Kenny AM, Kleppinger A, Annis K, Rathier M, Browner B, Judge JO, McGee $D$ : Effects of transdermal testosterone on bone and muscle in older men with low bioavailable testosterone levels, low bone mass, and physical frailty. J Am Geriatr Soc 2010, 58:1134-1143.

54. Marin P, Holmang S, Gustafsson C, Jonsson L, Kvist H, Elander A, Eldh J, Sjostrom L, Holm G, Bjorntorp P: Androgen treatment of abdominally obese men. Obes Res 1993, 1:245-251.

55. Spitzer M, Basaria S, Travison TG, Davda MN, Paley A, Cohen B, Mazer NA, Knapp PE, Hanka S, Lakshman KM, Ulloor J, Zhang A, Orwoll K, Eder R, Collins L, Mohammed N, Rosen RC, DeRogatis L, Bhasin S: Effect of testosterone replacement on response to sildenafil citrate in men with erectile dysfunction: a parallel, randomized trial. Ann Intern Med 2012, 157:681-691.

56. Srinivas-Shankar U, Roberts SA, Connolly MJ, O'Connell MD, Adams JE, Oldham JA, Wu FC: Effects of testosterone on muscle strength, physical function, body composition, and quality of life in intermediate-frail and frail elderly men: a randomized, double-blind, placebo-controlled study. J Clin Endocrinol Metab 2010, 95:639-650.

57. Malkin CJ, Pugh PJ, West JN, van Beek EJ, Jones TH, Channer KS: Testosterone therapy in men with moderate severity heart failure: a double-blind randomized placebo controlled trial. Eur Heart J 2006 27:57-64.

58. Merza Z, Blumsohn A, Mah PM, Meads DM, McKenna SP, Wylie K, Eastell R, Wu F, Ross RJ: Double-blind placebo-controlled study of testosterone patch therapy on bone turnover in men with borderline hypogonadism. Int J Androl 2006, 29:381-391.

59. Nair KS, Rizza RA, O'Brien P, Dhatariya K, Short KR, Nehra A, Vittone JL, Klee GG, Basu A, Basu R, Cobelli C, Toffolo G, Dalla Man C, Tindall DJ, Melton LJ 3rd, Smith GE, Khosla S, Jensen MD: DHEA in elderly women and DHEA or testosterone in elderly men. N Engl J Med 2006, 355:1647-1659.

60. Snyder PJ, Peachey H, Berlin JA, Rader D, Usher D, Loh L, Hannoush P, Dlewati A, Holmes JH, Santanna J, Strom BL: Effect of transdermal testosterone treatment on serum lipid and apolipoprotein levels in men more than 65 years of age. Am J Med 2001, 111:255-260.

61. Chapman IM, Visvanathan R, Hammond AJ, Morley JE, Field JB, Tai K, Belobrajdic DP, Chen RY, Horowitz M: Effect of testosterone and a nutritional supplement, alone and in combination, on hospital admissions in undernourished older men and women. Am J Clin Nutr 2009, 89:880-889.

62. Testosterone treatment of men with alcoholic cirrhosis: a double-blind study: the Copenhagen Study Group for Liver Diseases. Hepatology 1986, 6:807-813.

63. Emmelot-Vonk MH, Verhaar HJ, Nakhai Pour HR, Aleman A, Lock TM, Bosch $J$, Grobbee DE, van der Schouw YT: Effect of testosterone supplementation on functional mobility, cognition, and other parameters in older men: a randomized controlled trial. JAMA 2008 , 299:39-52.

64. Legros JJ, Meuleman EJ, Elbers JM, Geurts TB, Kaspers MJ, Bouloux PM, 43203 Investigators: Oral testosterone replacement in symptomatic late-onset hypogonadism: effects on rating scales and general safety in a randomized, placebo-controlled study. Eur J Endocrinol 2009, 160:821-831.

65. Arver S, Dobs AS, Meikle AW, Caramelli KE, Rajaram L, Sanders SW, Mazer NA: Long-term efficacy and safety of a permeation-enhanced testosterone transdermal system in hypogonadal men. Clin Endocrinol (Oxf) 1997 47:727-737.

66. Bhasin S, Travison TG, Storer TW, Lakshman K, Kaushik M, Mazer NA, Ngyuen AH, Davda MN, Jara H, Aakil A, Anderson S, Knapp PE, Hanka S, Mohammed N, Daou P, Miciek R, Ulloor J, Zhang A, Brooks B, Orwoll K, Hede-Brierley L, Eder R, Elmi A, Bhasin G, Collins L, Singh R, Basaria S: Effect of testosterone supplementation with and without a dual 5alpha-reductase inhibitor on fat-free mass in men with suppressed testosterone production: a randomized controlled trial. JAMA 2012, 307:931-939.

67. Lakshman KM, Kaplan B, Travison TG, Basaria S, Knapp PE, Singh AB, LaValley MP, Mazer NA, Bhasin S: The effects of injected testosterone dose and age on the conversion of testosterone to estradiol and dihydrotestosterone in young and older men. $J$ Clin Endocrinol Metab 2010, 95:3955-3964.

68. Raynaud JP, Legros JJ, Rollet J, Auges M, Bunouf P, Sournac M, Fiet J: Efficacy and safety of a new testosterone-in-adhesive matrix patch applied every 2 days for 1 year to hypogonadal men. $J$ Steroid Biochem Mol Biol 2008, 109:168-176.

69. Schubert M, Bullmann C, Minnemann T, Reiners C, Krone W, Jockenhovel F: Osteoporosis in male hypogonadism: responses to androgen substitution differ among men with primary and secondary hypogonadism. Horm Res 2003, 60:21-28.

70. Wang C, Harnett M, Dobs AS, Swerdloff RS: Pharmacokinetics and safety of long-acting testosterone undecanoate injections in hypogonadal men: an 84-week phase III clinical trial. J Androl 2010, 31:457-465.

71. Cherrier MM, Craft S, Matsumoto AH: Cognitive changes associated with supplementation of testosterone or dihydrotestosterone in mildly hypogonadal men: a preliminary report. J Androl 2003, 24:568-576.

72. Chiang HS, Hwang TI, Hsui YS, Lin YC, Chen HE, Chen GC, Liao CH: Transdermal testosterone gel increases serum testosterone levels in hypogonadal men in Taiwan with improvements in sexual function. Int J Impot Res 2007, 19:411-417.

73. Dean JD, Carnegie C, Rodzvilla J, Smith T: Long-term effects of testim(r) $1 \%$ testosterone gel in hypogonadal men. Rev Urol 2004, 6:S22-S29.

74. Di Luigi L, Sgro P, Aversa A, Migliaccio S, Bianchini S, Botre F, Romanelli F, Lenzi A: Concerns about serum androgens monitoring during testosterone replacement treatments in hypogonadal male athletes: a pilot study. J Sex Med 2012, 9:873-886.

75. Juang PS, Peng S, Allehmazedeh K, Shah A, Coviello AD, Herbst KL: Testosterone with dutasteride, but not anastrazole, improves insulin sensitivity in young obese men: a randomized controlled trial. J Sex Med 2014, 11:563-573.

76. Mazer N, Bell D, Wu J, Fischer J, Cosgrove M, Eilers B, Bs RN: Comparison of the steady-state pharmacokinetics, metabolism, and variability of a transdermal testosterone patch versus a transdermal testosterone gel in hypogonadal men. J Sex Med 2005, 2:213-226.

77. Page ST, Hirano L, Gilchriest J, Dighe M, Amory JK, Marck BT, Matsumoto AM: Dutasteride reduces prostate size and prostate specific antigen in older hypogonadal men with benign prostatic hyperplasia undergoing testosterone replacement therapy. J Urol 2011, 186:191-197.

78. Swerdloff RS, Wang C, Cunningham G, Dobs A, Iranmanesh A, Matsumoto AM, Snyder PJ, Weber T, Longstreth J, Berman N: Long-term pharmacokinetics of transdermal testosterone gel in hypogonadal men. J Clin Endocrinol Metab 2000, 85:4500-4510.

79. Wang C, Berman N, Longstreth JA, Chuapoco B, Hull L, Steiner B, Faulkner S, Dudley RE, Swerdloff RS: Pharmacokinetics of transdermal testosterone gel in hypogonadal men: application of gel at one site versus four sites: a General Clinical Research Center Study. J Clin Endocrinol Metab 2000, 85:964-969.

80. Wang C, Ilani N, Arver S, McLachlan Rl, Soulis T, Watkinson A: Efficacy and safety of the $2 \%$ formulation of testosterone topical solution applied to the axillae in androgen-deficient men. Clin Endocrinol (Oxf) 2011, 75:836-843. 
81. Ahmed SR, Boucher AE, Manni A, Santen RJ, Bartholomew M, Demers LM: Transdermal testosterone therapy in the treatment of male hypogonadism. J Clin Endocrinol Metab 1988, 66:546-551.

82. Bals-Pratsch M, Langer K, Place VA, Nieschlag E: Substitution therapy of hypogonadal men with transdermal testosterone over one year. Acta Endocrinol 1988, 118:7-13.

83. Behre HM, von Eckardstein S, Kliesch S, Nieschlag E: Long-term substitution therapy of hypogonadal men with transscrotal testosterone over 7-10 years. Clin Endocrinol (Oxf) 1999, 50:629-635.

84. Cunningham GR, Cordero E, Thornby Jl: Testosterone replacement with transdermal therapeutic systems: physiological serum testosterone and elevated dihydrotestosterone levels. JAMA 1989, 261:2525-2530.

85. Meikle AW, Mazer NA, Moellmer JF, Stringham JD, Tolman KG, Sanders SW, Odell WD: Enhanced transdermal delivery of testosterone across nonscrotal skin produces physiological concentrations of testosterone and its metabolites in hypogonadal men. J Clin Endocrinol Metab 1992, 74:623-628.

86. Franchimont $P$, Kicovic PM, Mattei A, Roulier R: Effects of oral testosterone undecanoate in hypogonadal male patients. Clin Endocrinol (Oxf) 1978 9:313-320.

87. Roth MY, Dudley RE, Hull L, Leung A, Christenson P, Wang C, Swerdloff R, Amory JK: Steady-state pharmacokinetics of oral testosterone undecanoate with concomitant inhibition of 5alpha-reductase by finasteride. Int J Androl 2011, 34:541-547.

88. van Coevorden A, Stolear JC, Dhaene M, van Herweghem JL, Mockel J: Effect of chronic oral testosterone undecanoate administration on the pituitary-testicular axes of hemodialyzed male patients. Clin Nephrol 1986, 26:48-54

89. Yarrow JF, McCoy SC, Borst SE: Intracrine and myotrophic roles of 5alphareductase and androgens: a review. Med Sci Sports Exerc 2012,44:818-826.

90. Stanczyk FZ, Azen CG, Pike MC: Effect of finasteride on serum levels of androstenedione, testosterone and their 5alpha-reduced metabolites in men at risk for prostate cancer. J Steroid Biochem Mol Biol 2013, 138:10-16.

91. Wang C, Shiraishi S, Leung A, Baravarian S, Hull L, Goh V, Lee PW, Swerdloff RS: Validation of a testosterone and dihydrotestosterone liquid chromatography tandem mass spectrometry assay: interference and comparison with established methods. Steroids 2008, 73:1345-1352.

92. Schoenfeld MJ, Shortridge E, Cui Z, Muram D: Medication adherence and treatment patterns for hypogonadal patients treated with topical testosterone therapy: a retrospective medical claims analysis. J Sex Med 2013, 10:1401-1409.

93. Donatucci C, Cui Z, Fang Y, Muram D: Long-term treatment patterns of testosterone replacement medications. J Sex Med 2014, 11:2092-2099.

94. Stout M, Tew GA, Doll H, Zwierska I, Woodroofe N, Channer KS, Saxton JM: Testosterone therapy during exercise rehabilitation in male patients with chronic heart failure who have low testosterone status: a double-blind randomized controlled feasibility study. Am Heart J 2012, 164:893-901.

95. Empen K, Lorbeer R, Dorr M, Haring R, Nauck M, Glaser S, Krebs A, Reffelmann T, Ewert R, Volzke H, Wallaschofski H, Felix SB: Association of testosterone levels with endothelial function in men: results from a population-based study. Arterioscler Thromb Vasc Biol 2012, 32:481-486.

doi:10.1186/s12916-014-0211-5

Cite this article as: Borst et al:: Cardiovascular risks and elevation of serum DHT vary by route of testosterone administration: a systematic review and meta-analysis. BMC Medicine 2014 12:211.

\section{Submit your next manuscript to BioMed Central and take full advantage of:}

- Convenient online submission

- Thorough peer review

- No space constraints or color figure charges

- Immediate publication on acceptance

- Inclusion in PubMed, CAS, Scopus and Google Scholar

- Research which is freely available for redistribution 